\title{
Cough in Patients With Lung Cancer
}

DOI:

10.1016/j.chest.2018.10.003

\section{Document Version}

Accepted author manuscript

Link to publication record in Manchester Research Explorer

\section{Citation for published version (APA):}

Harle, A. S. M., Blackhall, F. H., Molassiotis, A., Yorke, J., Dockry, R., Holt, K. J., Yuill, D., Baker, K., \& Smith, J. A. (2019). Cough in Patients With Lung Cancer: A Longitudinal Observational Study of Characterization and Clinical Associations. Chest, 155(1), 103-113. https://doi.org/10.1016/j.chest.2018.10.003

\section{Published in:}

\section{Chest}

\section{Citing this paper}

Please note that where the full-text provided on Manchester Research Explorer is the Author Accepted Manuscript or Proof version this may differ from the final Published version. If citing, it is advised that you check and use the publisher's definitive version.

\section{General rights}

Copyright and moral rights for the publications made accessible in the Research Explorer are retained by the authors and/or other copyright owners and it is a condition of accessing publications that users recognise and abide by the legal requirements associated with these rights.

\section{Takedown policy}

If you believe that this document breaches copyright please refer to the University of Manchester's Takedown Procedures [http://man.ac.uk/04Y6Bo] or contact uml.scholarlycommunications@manchester.ac.uk providing relevant details, so we can investigate your claim.

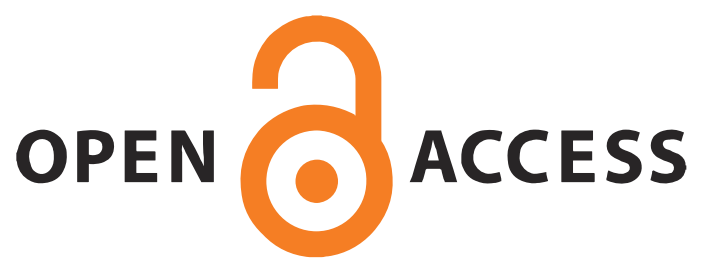




\section{Cough in patients with lung cancer: a longitudinal observational study of characterisation and clinical associations}

Amélie Harle $\mathrm{AS}^{\mathrm{a}, \mathrm{b}}$, Fiona H Blackhall ${ }^{\mathrm{b}, \mathrm{c}}$, Alex Molassiotis ${ }^{\mathrm{d}}$, Janelle Yorke ${ }^{\mathrm{e}, \mathrm{f}}$, Rachel Dockry ${ }^{\mathrm{g}}$, Kimberly Holt ${ }^{\mathrm{g}}$, Danielle Yuill ${ }^{\mathrm{g}}$, Katie Baker ${ }^{\mathrm{h}}$, Jaclyn A Smith ${ }^{\mathrm{g}, \mathrm{i}}$.

a, Dorset Cancer Centre, Poole NHS Foundation Trust, UK

${ }^{\mathrm{b}}$ Department of Medical Oncology, The Christie NHS Foundation Trust, UK

${ }^{c}$ Division of Cancer Sciences, University of Manchester, Manchester, UK

${ }^{d}$ School of Nursing, The Hong Kong Polytechnic University, Hong Kong

e Division of Nursing, Midwifery and Social Work, School of Health Sciences, University of Manchester, Manchester, UK

${ }^{\dagger}$ Department of Christie Patient Centred Research, The Christie NHS Foundation Trust, Manchester, UK

${ }^{9}$ Division of Infection, Immunity and Respiratory Medicine, University of Manchester, Manchester, UK

${ }^{\mathrm{h}}$ Clinical and Experimental Pharmacology Group, Cancer Research UK Manchester Institute, University of Manchester, UK

' Manchester University NHS Foundation Trust, Manchester, UK

Corresponding Author:

Dr Amélie Harle - Dorset Cancer Centre, Poole NHS Foundation Trust, Longfleet Road, Poole BH15 2LB. Amelie.Harle@poole.nhs.uk

Word Count: 2535

\section{CONFLICTS OF INTEREST}

JS is a named Inventor on a patent describing detection of cough from sound recordings. The patent is owned by University Hospital of South Manchester and licensed to Vitalograph Ltd. AH, RD, KH, DY, AM, KB, JY and FHB have no conflicts of interest to declare.

\section{FUNDING}

This work was funded by an NIHR fellowship award [DRF-2010-03-55] and was supported by the North West Lung Charity.

\section{ABSTRACT}


Background: Cough is common in patients with lung cancer and current antitussive treatments are suboptimal. There is little published data describing cough in patients with lung cancer or work assessing clinical associations; the aim of the current is study is to fill that gap.

Methods: Longitudinal prospective observational single-cohort study over 60 days. Patients were assessed through self-reported validated scales and, in a subsample, ambulatory cough monitoring, at study entry (day 0), day 30 and day 60.

Results: At study entry, 177 patients were included and 153 provided data at day 60 . The median duration of cough was 52 weeks (IQR 8.5-260). Cough was described as severe enough to warrant treatment in $62 \%$ of the patients. Depending on the scale used, performance status was associated with both cough severity and cough impact $(p<0.001)$ at study entry, while higher cough severity at study entry was associated with female sex $(p=0.02)$, asthma $(p=0.035)$, and reflux disease $(p<0.001)$; cough impact at study entry was additionally associated with experiencing nausea $(p=0.018)$. Cancer characteristics (i.e. cancer stage, histology) were not associated with cough severity nor cough impact; neither was smoking or COPD.

Conclusions: This is the first study to describe characteristics of cough in patients with lung cancer and identify clinical associations that may be relevant for its treatment. Our data suggest that cough is a frequent and distressing symptom, and an unmet clinical need. Its associationwith gastro-intestinal symptoms in this study may improve our understanding of pathophysiology and therapeutic options for cough occurring in patients with lung cancer.

Keywords: cough, lung cancer, severity, assessment 


\section{INTRODUCTION}

Cough in patients with lung cancer is an unmet clinical need for which morbidity and distress have been underestimated ${ }^{1,2}$. It impacts on physical, psychological and social aspects of daily living ${ }^{2,3}$, contributes to pain, fatigue, insomnia \& dyspnoea ${ }^{2}$, increases anxiety in patients and carers ${ }^{2,4}$ and leads to social isolation ${ }^{2}$. Although cough is a common symptom, its prevalence varies widely between studies from $31.5 \%-93 \%^{5,6}$. This may be explained by differing methodologies and approaches to cough assessment, and heterogeneous populations of lung cancer patients evaluated. Notably, there is very little understanding of the possible mechanisms underlying cough among patients with lung cancer ${ }^{7}$ which has implications for the development of effective antitussive therapies. Furthermore, studies of cough in patients with lung cancer should ideally employ validated objective and subjective cough assessment tools.

Our group has recently demonstrated the validity of subjective and objective cough assessment tools for patients with lung cancer; including the cough severity visual analogue scale, the Manchester Cough in Lung Cancer Scale to assess cough impact and 24-hour ambulatory cough monitoring to assess cough frequency ${ }^{5,8}$. This provides opportunity to assess and describe cough in the lung cancer population and in the future to employ in trials of novel antitussive agents in patients with lung cancer. In order to design such studies information about cough prevalence, severity, impact, clinical associations, causes and treatment is required. There is a paucity of data on these factors in patients with lung cancer probably due to inadequate cough assessment tools and limited research where cough is the primary outcome.

Given the availability of lung cancer-specific tools for cough assessment and emerging data on cough mechanisms and novel antitussive therapies, this study was conducted to describe the characteristics of cough in patients with lung cancer and to obtain information on its change over time. Specific objectives included: i) to determine how cough severity, 
frequency and impact in patients with lung cancer changes over time; and ii) to assess for clinical factors associated with cough severity and cough impact over time.

\section{METHODS}

This was a longitudinal observational study. Patients attending a thoracic oncology outpatient clinic were invited to enrol in a 60-day single-arm cohort study to assess cough. Patients were eligible to participate if they had a diagnosis of lung cancer, reported a cough on direct questioning by the treating team or researchers, were able to comply with the study schedule and were able to read and respond to questions in English. Written informed consent was obtained from all study participants. The study was approved by the local research ethics committee (REC 11/NW/0374).

Non-consecutive patients on pre-specified days were screened, and those reporting cough and agreeing to participate completed a set of assessments at study entry (Day 0), Day 30 and Day 60 (group A \& B, see Figure 1). Patients completed a number of self-reported scales. A subsample also underwent a $24 \mathrm{hr}$ ambulatory cough monitoring upon study entry and at Day 60 (group B). Eligible participants were assigned to Group A if they consented to the study but declined 24-hour ACM, or to Group B if they consented both to the study and to 24-hour ACM.

\section{Assessment tools}

Manchester Cough in Lung Cancer (MCLC) scale: a 10-item lung cancer cough-specific quality of life (QoL) questionnaire which includes items on cough frequency, distress, impact and severity ${ }^{9}$. Scores range from 1-50, with higher scores indicating a worse cough-related QoL. This was completed at study entry, day 30 and day 60.

Cough Severity Visual Analogue Scale $(\mathrm{VAS})^{10}$ : a $100 \mathrm{~mm}$ line marked with "no cough" at Omm and "worst cough" at $100 \mathrm{~mm}$. Patients were asked to mark along the line to represent their perceived cough severity. This was completed at study entry, day 30 and day 60 . 
Cough Severity Diary $(\mathrm{CSD})^{11}$ : a cough assessment tool that has seven 11-point scales ranging from scores of 0 to 10 that assess severity in terms of disruptiveness (two items), frequency (three items) and intensity (two items). The CSD total score, representing the magnitude of cough severity, is calculated by averaging across all seven items. Higher scores indicate worse cough severity. This was completed at study entry and day 60 .

The single item (item 31) for the assessment of cough from the European Organisation for Research and Treatment of Cancer Quality of Life Questionnaire's (EORTC QLQ C30)-Lung Cancer module (LC-13) ${ }^{12}$ was used. It states: "During the past week, how much did you cough?", answered on a 4-point Likert scale: Not at all to Very much. This was completed at study entry and day 60 .

Common Terminology Criteria for Adverse Events version 4.0 (CTCAEv4): a symptom tool which documents clinician-assessed cancer treatment-related toxicities ${ }^{13}$. The cough item is a 3-point scale, where high scores represent highest symptomatology. This was completed at Day 0 and 60 .

Brief Reflux Inventory (BRI): a 5-item scale to assess reflux ${ }^{14}$. Its items relate to symptoms of regurgitation, chest pain/burning and nocturnal symptoms. Each item has five response categories; "never", "rarely", "once a month to once a week", "at least twice a week" and "daily". The scale is scored $0-5$, where $0=$ "never" and $5=$ "daily". The total weighted score is the sum of the weighted scores for the 5 individual items of the inventory. Patients with a total BRI score above 31.6 are defined as those with reflux disease. This was completed at Day 0 and 60.

World Health Organization (WHO) Performance Status (PS): categorises a patient's overall health status ${ }^{15}$. Scores range from $0-5$, with higher scores indicating a poorer overall performance status. The WHO PS was completed by a researcher on Day 0 and 60 .

Cough frequency was assessed using an objective ambulatory cough monitoring (ACM) at Day 0 and 60 only. ACM is an objective cough assessment tool to determine the frequency 
of cough events ${ }^{16,17}$. A contact sensor is applied below the sternal notch and microphone attached to the lapel connected to the VitaloJAK Cough Monitor® (Vitalograph Ltd, UK), which is carried in a waist bag. Validated custom-written software algorithms are used to compress the recording from 24 hours to a shorter file by detecting all potential cough sounds. Trained staff then listen to the reduced file and manually tag the number of explosive cough sounds within the recording using an audio editing software package (Adobe ${ }^{\circledR}$ Audition ${ }^{\circledR}$ 3.0) to produce an hour by hour cough count report, previously validated $^{18-20}$.

\section{Sample size estimation}

We estimated that 178 patients would be recruited for a sample size for analysis of 160 . This is based on Peduzzi ${ }^{21}$ for 10 participants per variable in binary logistic regression, assuming an attrition rate of $10 \%$, the estimated percentage presenting with a severe cough to be $50 \%$, and the number of cough predictors to be 8 . The clinical factors investigated were: time from diagnosis, age, gender, smoking (never vs current/ex), stage (early vs late), histology (small cell lung cancer (SCLC) vs non-small cell lung cancer (NSCLC)), tumour location (peripheral vs central), presence of co morbidities and co-medications. Of note, when squamous cell and adenocarcinoma were analysed separately, histological subtypes did still not predict cough severity or impact.

Forty patients were required for ambulatory cough monitoring in order to detect medium-tohigh (0.40) and high (0.50) correlations between quality of life and subjective measures and ambulatory cough monitoring. The numbers needed at $5 \%$ significance and $80 \%$ power with a one-sided test were 37 and 23 respectively for Pearson's and Spearman's correlations.

\section{Statistical Analysis}

Statistical analyses were performed using SPSS (v.19.0). Descriptive statistics were used to summarise the data. Multivariate linear regression analyses, adjusted for baseline scores, were used to determine factors associated with cough severity, frequency and impact and their change over time. 


\section{RESULTS}

\section{Sample characteristics}

696 patients were screened and 257 reported cough. From those, 178 patients consented to participate in the study, 177 completed study entry data and 153 patients completed assessments at day 60 (attrition rate=14\%) (Figure 1). The clinical characteristics of the study population are shown in Table 1.

\section{Cough Characteristics at Study Entry}

The median duration of reported cough at study entry was 52 weeks (IQR 8.5-260). This preceded cancer diagnosis by a median of 12.4 weeks but varied considerably between individuals (range -262.4 to 3895 weeks) and $36.2 \%$ of participants reported that cough started after the cancer diagnosis. Overall, $104(62 \%)$ patients $(n=167)$ stated that their cough was severe enough to warrant treatment. The characteristics of cough at study entry are shown in Table 2.

\section{Changes in clinical characteristics and cough scores over time}

Three variables changed significantly over the course of the study: 1) the median FEV1 values (1.52I, IQR 1.20-2.03 on day 0 vs 1.62 I, IQR 1.24-1.63 on day 60 , p-value 0.05 ), although this small difference is unlikely to be of clinical significance 2) the proportion of patients receiving anticancer therapy; $49 \%$ on day 30 (81/167 patients) compared to $35 \%$ (62/176 patients) on day 0 and $40 \%$ (61/149 patients) on day 60 , ( $\mathrm{p}$-value 0.04$)$, and 3 ) the proportion of patients who were pre-cancer therapy.

In the overall study population cough scores improved over the course of the study, irrespective of the subjective cough assessment tool used (Figure 2). Most of the improvement occurred during the Day 0-30 interval, rather than the Day 0-60 interval for the VAS, MCLC and CTCAE. The CSD and EORTC LC13 Item 31 "How often did you cough?" were not assessed on Day 30, however, overall scores also improved between Day 0 and Day 60. There was significant overlap between the cough scores at all assessment points. In 
contrast, the objective 24-hour ACM rates did not significantly change between Day 0 and 60.

\section{Clinical factors associated with cough impact (MCLC) and cough severity (VAS) scores}

The analyses were conducted for patients at study entry and for change in cough over time periods day 0 - day 30 and day 0 - day 60 . Clinical factors associated with both cough severity (VAS score) and cough impact on quality of life (MCLC score) were determined on univariate and multivariate analyses. These are shown in Tables 3-5. Similar clinical characteristics were associated with cough severity and cough impact at study entry and over time. At study entry, performance status was significantly associated with both cough severity VAS and cough impact MCLC scores on both univariate and multivariate analyses. Notably, cancer characteristics (i.e. cancer stage, histology) were not associated with cough severity/impact scores; neither were smoking or COPD. However, gastro-intestinal symptoms, specifically nausea and reflux were associated with cough severity and cough impact at study entry in the univariate analysis.

Cough severity/impact and reported use of opioids and other anti-tussive treatments exhibited interesting associations. At study entry, cough severity was worse in those taking anti-tussive therapies and impact worse in those on opioids on univariate analysis. However, those taking opioids and antitussives at 30 and 60 day follow up where more likely to have some improvements in cough severity and/or impact. Similarly those on antitussive therapies were more likely to report improvement in cough severity over time.

\section{DISCUSSION}

This study is the first study to describe the characteristics of cough in patients with lung cancer longitudinally over a 60-day period using validated subjective cough assessment tools and objective ambulatory cough monitoring. The use of these assessments provides a benchmark of cough severity, frequency, impact, change over time and clinical associations in a 'real world' population of patients with lung cancer. 
We previously showed that $57 \%$ of consecutive patients with lung cancer $(n=223)$

experienced cough, with the majority stating that their cough warranted treatment and with $23 \%$ reporting a painful cough ${ }^{22}$. In this study, over two thirds of patients with lung cancer and a cough expressed that their cough was severe enough to warrant treatment. The median cough severity scores at study entry demonstrated that this cohort of patients with lung have a severe and frequent cough; worse than reported in patients with COPD and asthma ${ }^{18,19}$ and as severe and frequent as in patients who present to specialist chronic cough clinics with cough as their primary symptom ${ }^{20}$.

Despite this, only $15 \%$ of patients in this study reported the use of over-the-counter antitussives. One possible explanation may be that patients themselves, or health care professionals recognise the lack of efficacy of such treatments. It is notable that at study entry, anti-tussive, opioid and steroid therapies were associated with a worse cough. We did not ascertain whether opioid treatment was prescribed specifically to treat cough as opposed to pain or breathlessness. However we observed that within individuals opioid use was associated with improvement in cough severity and impact over time, implying a potential therapeutic benefit, perhaps analogous to that seen in patients with chronic refractory cough $^{23}$. This longitudinal, observational study is the first to associate cough severity and impact with nausea and reflux disease, rather than cancer related factors such as the stage of the cancer, its location or histological type. Neither smoking, nor the presence of COPD was associated with worse reported cough severity or cough-related quality of life. Whilst the associations between cough and reflux/regurgitation at study entry are reminiscent of the reflux-cough relationships well-described in patients with refractory chronic cough, it was also revealing that nausea, another vagally mediated symptom, was significantly associated with cough. Although coughing may lead to nausea and vomiting, a cluster analysis of symptoms from a broad range of patients with cancer suggested gastro-intestinal symptoms including nausea tend to be co-reported by patients with cough and breathlessness ${ }^{24}$. Such clusters of co-reported symptoms may be explained by shared physiological mechanisms 
and this particular cluster of symptoms is in keeping with a set of symptoms mediated by the vagus nerve.

Although this study was longitudinal, the time period of 60 days is short compared to the overall disease trajectory. This may have been partly overcome by the fact that patients were enrolled at any stage on their disease trajectory in a relatively large cohort of patients. However, few patients enrolled on the study were receiving curative-intent treatment and few patients were at the end of life; therefore the severity and burden of cough in those groups is not well represented. The day 30 assessment was limited to the MCLC and VAS scales only to reduce the burden of a day 30 hospital visit. Since the VAS required completion at home and return by post, only $62 \%$ patients completed this scale at day 30 , limiting the analysis of this outcome measure. as Also, pulmonary function tests were obtained by the use of a hand-held spirometry device which can underestimate changes in pulmonary function.

In conclusion, using validated objective and subjective cough assessment tools we confirm that cough is a severe and distressing symptom in patients with lung cancer. Current antitussive therapies have limited efficacy with a weak evidence base ${ }^{25}$. Importantly, gastrointestinal symptoms demonstrated an association with cough rather than smoking, cancer stage, location, treatment and COPD. Recent research in the non-cancer setting has elucidated central nervous system circuitry and pathways common to cough and the gastrointestinal tract leading to a more comprehensive understanding of cough neurochemistry and higher order control of coughing ${ }^{26,27}$. As a result, new potential targets for antitussive

therapies have been identified that may be relevant to patients with lung cancer ${ }^{28,29}$. Specific management of reflux and nausea may also alleviate cough in this population of patients.

\section{ACKNOWLEDGEMENTS}

The authors would like to thank the patients for their participation; and the clinicians who enabled the conduct of this study in their clinics. This work was supported by The Cancer 
Research UK (CRUK) Manchester Institute, The National Institute for Health Research

(NIHR) South Manchester Respiratory and Allergy Clinical Research Facility and The NIHR

Christie Clinical Research Facility. The views expressed are those of the author(s) and not

necessarily those of the NHS, the NIHR or the Department of Health. Author contributions

were as follows; Conception and design: $\mathrm{AH}, \mathrm{FHB}, \mathrm{JS}$ and JY; data generation, analysis and

interpretation: $A H, K H$, DY, RD, JS, JY and FHB; writing the paper: $A H, A M, J S, F H B$. All

authors reviewed the manuscript and approved the final draft.

\section{REFERENCES}

1. Kvale PA. Chronic cough due to lung tumors: ACCP evidence-based clinical practice guidelines. Chest 2006;129(1 Suppl):147S-153S.

2. Molassiotis A, Lowe M, Ellis J, et al. The experience of cough in patients diagnosed with lung cancer. Support Care Cancer 2011;19(12):1997-2004.

3. Tishelman C, Petersson L-M, Degner LF, Sprangers MAG. Symptom prevalence, intensity, and distress in patients with inoperable lung cancer in relation to time of death. $J$ Clin Oncol 2007;25(34):5381-9.

4. Buchanan D, Milroy R, Baker L, Thompson AM, Levack PA. Perceptions of anxiety in lung cancer patients and their support network. Support Care Cancer 2010;18(1):29-36.

5. Iyer S, Roughley A, Rider A, Taylor-Stokes $G$. The symptom burden of non-small cell lung cancer in the USA: a real-world cross-sectional study. Support Care Cancer 2014;22(1):181-7.

6. Hernández IS, Alonso JLI, Sánchez CA. [Epidemiology of lung cancer in Spain and forecast for the future]. Arch Bronconeumol 2006;42(11):594-9.

7. Harle ASM, Blackhall FH, Smith JA, Molassiotis A. Understanding cough and its management in lung cancer. Curr Opin Support Palliat Care 2012;6(2):153-62.

8. Harle Molassiotis A, Smith JA, Blackhall FH ASM. The "CLiC" Cough in Lung Cancer Study: the validation of objective and subjective cough assessment tools in lung cancer patients. $J$ Thorac Oncol 2013;8.

9. Molassiotis A, Ellis J, Wagland R, et al. The Manchester cough in lung cancer scale: the development and preliminary validation of a new assessment tool. J Pain Symptom Manage 2013;45(2):179-90.

10. Brightling $\mathrm{CE}$, Monterio W, Green $\mathrm{RH}$, et al. Induced sputum and other outcome measures in chronic obstructive pulmonary disease: safety and repeatability. Respir Med 2001;95(12):999-1002.

11. Vernon M, Kline Leidy N, Nacson A, Nelsen L. Measuring cough severity: development and pilot testing of a new seven-item cough severity patient-reported outcome measure. Ther Adv Respir Dis 2010;4(4):199-208.

12. Bergman B, Aaronson NK, Ahmedzai S, Kaasa S, Sullivan M. The EORTC QLQ-LC13: a modular supplement to the EORTC Core Quality of Life Questionnaire (QLQ-C30) for use in lung cancer clinical trials. EORTC Study Group on Quality of Life. Eur J Cancer 1994;30A(5):635-42.

13. Trotti A, Colevas AD, Setser A, et al. CTCAE v3.0: development of a comprehensive grading system for the adverse effects of cancer treatment. Semin Radiat Oncol 2003;13(3):176-81.

14. Zimmerman J. Validation of a brief inventory for diagnosis and monitoring of symptomatic gastrooesophageal reflux. Scand J Gastroenterol 2004;39(3):212-6.

15. Oken MM, Creech $\mathrm{RH}$, Tormey DC, et al. Toxicity and response criteria of the Eastern Cooperative Oncology Group. Am J Clin Oncol 1982;5(6):649-55.

16. Smith J, Owen E, Earis J, Woodcock A. Effect of codeine on objective measurement of cough in chronic obstructive pulmonary disease. J Allergy Clin Immunol 2006;117(4):831-5.

17. Smith JA, Owen EC, Jones AM, Dodd ME, Webb AK, Woodcock A. Objective measurement of cough during pulmonary exacerbations in adults with cystic fibrosis. Thorax 2006;61(5):425-9.

18. Sumner $\mathrm{H}$, Woodcock $\mathrm{A}$, Kolsum $\mathrm{U}$, et al. Predictors of objective cough frequency in chronic obstructive pulmonary disease. Am J Respir Crit Care Med 2013;187(9):943-9.

19. Marsden PA, Smith JA, Kelsall AA, et al. A comparison of objective and subjective measures of cough in asthma. J Allergy Clin Immunol 2008;122(5):903-7.

20. Kelsall A, Decalmer S, McGuinness K, Woodcock A, Smith JA. Sex differences and predictors of objective cough frequency in chronic cough. Thorax 2009;64(5):393-8.

21. Peduzzi P, Concato J, Kemper E, Holford TR, Feinstein AR. A simulation study of the number of events per variable in logistic regression analysis. J Clin Epidemiol 1996;49(12):1373-9. 
22. Harle ASM, Buffin O, Burnham J, Molassiotis A, Blackhall FH, Smith JA. The prevalence of cough in lung cancer: Its characteristics and predictors. J Clin Oncol 2014;32(31_suppl):162.

23. Morice $\mathrm{AH}$, Menon MS, Mulrennan SA, et al. Opiate therapy in chronic cough. Am J Respir Crit Care Med 2007;175(4):312-5.

24. Cleeland CS, Mendoza TR, Wang XS, et al. Assessing symptom distress in cancer patients: the M.D. Anderson Symptom Inventory. Cancer 2000;89(7):1634-46.

25. Molassiotis A, Bailey C, Caress A, Tan J-Y. Interventions for cough in cancer. Cochrane database Syst Rev 2015;5:CD007881.

26. Canning BJ, Farmer DGS. Regulation of cough by neuronal $\mathrm{Na}(+)-\mathrm{K}(+)$ ATPases. Curr Opin Pharmacol 2015;22:140-5.

27. Bonvini SJ, Birrell MA, Grace MS, et al. Transient receptor potential cation channel, subfamily V, member 4 and airway sensory afferent activation: Role of adenosine triphosphate. J Allergy Clin Immunol 2016;138(1):249-261.e12.

28. Abdulqawi R, Dockry $\mathrm{R}$, Holt $\mathrm{K}$, et al. P2X3 receptor antagonist (AF-219) in refractory chronic cough: a randomised, double-blind, placebo-controlled phase 2 study. Lancet (London, England) 2015;385(9974):1198-205.

29. Harle J; Molassiotis, A; Lofthouse, K; Dockry, R; Russell, P; Burns, K; Blackhall, Fiona H AS. A placebocontrolled trial of aprepitant for cough in lung cancer. J Clin Oncol 2016;33(29). 
Table 2: Cough characteristics at study entry. VAS cough severity Visual Analogue Scale (patient reported); MCLC Manchester Cough in Lung Cancer scale (patient reported); CSD Cough Severity Diary (patient reported); EORTC QLQ C30+LC13 European Organization for the Research and Treatment of Cancer Quality of Life Core30 questionnaire and Lung Cancer LC13 module (patient reported); CTCAE Common Terminology for Adverse Events cough severity grading scale (patient reported); ACM Ambulatory Cough Monitoring, SD Standard Deviation, IQR interquartile range

\begin{tabular}{|c|c|}
\hline Cough Assessment Tool & \\
\hline $\begin{array}{l}\text { Cough Severity VAS (range } 0-100 \mathrm{~mm}) \mathrm{n}=171 \\
\text { Median }\left(25-75^{\text {th }} \text { IQR) }\right.\end{array}$ & $40 \mathrm{~mm}(20-69)$ \\
\hline $\begin{array}{l}\text { Cough Impact MCLC (range 1-50) } n=165 \\
\text { Median }\left(25^{\text {th }}-75^{\text {th }} \text { IQR) }\right.\end{array}$ & $24(18-32)$ \\
\hline $\begin{array}{l}\text { Cough Severity CSD (range } 0-10) n=87 \\
\text { Median }\left(25^{\text {th }}-75^{\text {th }} \text { IQR) }\right.\end{array}$ & $2.9(1.5-8.0)$ \\
\hline $\begin{array}{l}\text { EORTC QLQ C30+LC13 Cough Severity Item } 31 \text { (range 0-100) n=173 } \\
\text { Mean (SD) }\end{array}$ & $60.7(29)$ \\
\hline $\begin{array}{l}\text { Cough Severity CTCAE v4.0 (range 1-3) n=176 } \\
\mathrm{n}(\%) \\
\text { Grade } 1 \\
\text { Grade } 2 \\
\text { Grade } 3\end{array}$ & $\begin{array}{l}92(52 \%) \\
82(47 \%) \\
2(1 \%)\end{array}$ \\
\hline $\begin{array}{l}\text { Cough Frequency ACM (coughs/hour) } n=39 \\
\text { Median }\left(25^{\text {th }}-75^{\text {th }} \text { IQR) }\right.\end{array}$ & $14.1 \mathrm{c} / \mathrm{h}(6.3-31.9)$ \\
\hline $\begin{array}{l}\text { Patient Question } \mathrm{n}=167 \\
\text { "Does your cough warrant treatment?" }\end{array}$ & Yes 104 (62\%) \\
\hline
\end{tabular}


Table 3. Clinical factors associated with cough severity. VAS and cough impact MCLCS scores at study entry. NS Non significant; VAS cough severity Visual Analogue Scale; MCLC Manchester Cough in Lung Cancer scale; COPD Chronic Obstructive Pulmonary Disease; PS performance status. *Item 5 of BRI excluded since contained the cough within the question "Are you ever woken up at night by a feeling of heartburn, coughing or choking?"

\begin{tabular}{|c|c|c|c|c|c|}
\hline $\begin{array}{l}\text { Cough } \\
\text { Predictors }\end{array}$ & Description & $\begin{array}{l}\text { Univariate } \\
\text { Analysis } \\
\text { VAS score } \\
\text { Study Entry } \\
n=167-171\end{array}$ & $\begin{array}{l}\text { Multivariate } \\
\text { Analysis } \\
\text { VAS Study Entry } \\
\mathrm{n}=167 \mathrm{p}<0.001 \\
\mathrm{R}^{2} 25 \%\end{array}$ & $\begin{array}{l}\text { Univariate } \\
\text { Analysis } \\
\text { MCLCS } \\
\text { score Study } \\
\text { Entry } \\
\text { n-160-165 }\end{array}$ & $\begin{array}{l}\text { Multivariate } \\
\text { Analysis } \\
\text { MCLCS } \\
\text { Entryn=156 } \\
<0.001 \\
R^{2} 29 \%\end{array}$ \\
\hline Gender & $\begin{array}{l}\text { Women } \\
\text { worse }\end{array}$ & $p=0.048$ & $\mathrm{p}=0.020$ & NS & - \\
\hline $\begin{array}{l}\text { Performanc } \\
\text { e Status }\end{array}$ & $\begin{array}{ll}\text { PS } & 2-3 \\
\text { worse } & \end{array}$ & $p<0.001$ & $p=0.001$ & $p<0.001$ & $p=0.001$ \\
\hline Smoking & & NS & - & NS & - \\
\hline Asthma & $\begin{array}{l}\text { Asthma } \\
\text { worse }\end{array}$ & $p=0.021$ & $\mathrm{p}=0.035$ & $\mathrm{p}=0.054$ & - \\
\hline COPD & & NS & - & NS & - \\
\hline $\begin{array}{l}\text { Chest } \\
\text { Infection }\end{array}$ & $\begin{array}{l}\text { Chest } \\
\text { Infection } \\
\text { worse }\end{array}$ & $\mathrm{p}=0.022$ & - & $p=0.044$ & - \\
\hline \multirow[t]{4}{*}{$\begin{array}{l}\text { Reflux } \\
\text { Disease }\end{array}$} & \multirow[t]{4}{*}{$\begin{array}{l}\text { Reflux } \\
\text { worse }\end{array}$} & \multirow[t]{4}{*}{$\begin{array}{l}\text { Total score: } \\
p<0.001\end{array}$} & $\begin{array}{l}\text { Q1: } \\
\text { Pain/pressure/burn } \\
\text { ing? } \\
p=0.91\end{array}$ & \multirow[t]{4}{*}{$\begin{array}{l}\text { Total score: } \\
p<0.001\end{array}$} & $\begin{array}{l}\text { Q1: } \\
\text { Pain/pressure/burni } \\
\text { ng? } \\
p=0.83\end{array}$ \\
\hline & & & $\begin{array}{l}\text { Q2: Burning in } \\
\text { throat? } \\
\mathrm{p}=0.12\end{array}$ & & $\begin{array}{l}\text { Q2: Burning in } \\
\text { throat? } \\
p=0.60\end{array}$ \\
\hline & & & $\begin{array}{l}\text { Q3: Sour taste? } \\
P=0.84\end{array}$ & & $\begin{array}{l}\text { Q3: Sour taste? } \\
P=0.69\end{array}$ \\
\hline & & & $\begin{array}{l}\text { Q4: Regurgitation? } \\
p=0.005\end{array}$ & & $\begin{array}{l}\text { Q4: Regurgitation? } \\
\mathrm{P}=0.13\end{array}$ \\
\hline Nausea & $\begin{array}{l}\text { Nausea } \\
\text { worse }\end{array}$ & $p=0.01$ & - & $p<0.001$ & $p=0.018$ \\
\hline Stage & & NS & - & NS & - \\
\hline Histology & & NS & - & NS & - \\
\hline $\begin{array}{l}\text { Tumour } \\
\text { Location }\end{array}$ & $\begin{array}{l}\text { Central } \\
\text { tumour } \\
\text { worse }\end{array}$ & NS & - & $p=0.040$ & - \\
\hline $\begin{array}{l}\text { Anticancer } \\
\text { Treatment }\end{array}$ & $\begin{array}{l}\text { Off } \\
\text { treatment } \\
\text { worse }\end{array}$ & $p=0.048$ & - & NS & - \\
\hline Opioids & $\begin{array}{l}\text { On opioids } \\
\text { worse }\end{array}$ & NS & - & $p=0.018$ & - \\
\hline Steroids & $\begin{array}{l}\text { On steroids } \\
\text { worse }\end{array}$ & NS & - & $p=0.017$ & - \\
\hline $\begin{array}{l}\text { Antitussive } \\
\mathrm{s}\end{array}$ & $\begin{array}{l}\text { On } \\
\text { antitussives } \\
\text { worse }\end{array}$ & $p=0.011$ & & NS & - \\
\hline
\end{tabular}


Table 4 Clinical factors associated with a change in cough severity VAS and cough impact MCLCS scores "day 0- 30 interval". NS Non significant; VAS cough severity Visual Analogue Scale; MCLC Manchester Cough in Lung Cancer scale; COPD Chronic Obstructive Pulmonary Disease; PS performance status. *Item 5 of BRI excluded since contained the cough within the question "Are you ever woken up at night by a feeling of heartburn, coughing or choking?"

\begin{tabular}{|c|c|c|c|c|c|}
\hline $\begin{array}{l}\text { Cough } \\
\text { Predictors }\end{array}$ & Description & $\begin{array}{l}\text { Univariate } \\
\text { Analysis } \\
\text { Day 0-30 } \\
\text { Change in } \\
\text { VAS score } \\
n=103\end{array}$ & $\begin{array}{l}\text { Multivariate Analysis } \\
\text { Day 0-30 } \\
\text { Change in VAS score } \\
n=103 p<0.001 \\
R^{2} 36.7 \%\end{array}$ & $\begin{array}{l}\text { Univariate } \\
\text { Analysis } \\
\text { Day 0-30 } \\
\text { Change in } \\
\text { MCLC } \\
\text { score } \\
\mathrm{n}=148\end{array}$ & $\begin{array}{l}\text { Multivariate Analysis } \\
\text { Day 0-30 } \\
\text { Change in MCLC score } \\
n=147 p<0.001 \\
R^{2} 37.5 \%\end{array}$ \\
\hline Age & & NS & - & NS & - \\
\hline Gender & & NS & - & NS & - \\
\hline $\begin{array}{l}\text { Performance } \\
\text { Status }\end{array}$ & $\begin{array}{l}\text { PS } 1 \text { at study } \\
\text { entry = } \\
\text { greater } \\
\text { improvement }\end{array}$ & $p=0.04$ & NS & $\mathrm{p}=0.007$ & NS \\
\hline Smoking & & NS & - & NS & - \\
\hline Asthma & & NS & - & NS & - \\
\hline COPD & & NS & - & NS & - \\
\hline $\begin{array}{l}\text { Chest } \\
\text { Infection }\end{array}$ & & NS & - & NS & - \\
\hline \multirow[t]{4}{*}{$\begin{array}{l}\text { Reflux } \\
\text { Disease }\end{array}$} & $\begin{array}{l}\text { Reflux worse } \\
\text { at study } \\
\text { entry = } \\
\text { greater } \\
\text { improvement }\end{array}$ & $\begin{array}{l}\text { Total } \\
\text { score: } \\
p=0.04\end{array}$ & $\begin{array}{l}\text { Q1: } \\
\text { Pain/pressure/burning? } \\
\text { NS }\end{array}$ & $\begin{array}{l}\text { Total } \\
\text { score: } \\
p=0.04\end{array}$ & $\begin{array}{l}\text { Q1: } \\
\text { Pain/pressure/burning? } \\
\text { NS }\end{array}$ \\
\hline & & & $\begin{array}{l}\text { Q2: Burning in throat? } \\
\text { NS }\end{array}$ & & $\begin{array}{l}\text { Q2: Burning in throat? } \\
\text { NS }\end{array}$ \\
\hline & & & $\begin{array}{l}\text { Q3: Sour taste? } \\
\text { NS }\end{array}$ & & $\begin{array}{l}\text { Q3: Sour taste? } \\
\text { NS }\end{array}$ \\
\hline & & & $\begin{array}{l}\text { Q4: Regurgitation? } \\
\text { NS }\end{array}$ & & $\begin{array}{l}\text { Q4: Regurgitation? } \\
\text { NS }\end{array}$ \\
\hline Nausea & & NS & - & NS & - \\
\hline Stage & & NS & - & NS & - \\
\hline Histology & & NS & - & NS & - \\
\hline $\begin{array}{l}\text { Tumour } \\
\text { Location }\end{array}$ & & NS & - & NS & - \\
\hline $\begin{array}{l}\text { Anticancer } \\
\text { Treatment }\end{array}$ & & NS & - & NS & - \\
\hline Opioids & $\begin{array}{l}\text { On opioids at } \\
\text { study entry = } \\
\text { greater } \\
\text { improvement }\end{array}$ & $p=0.014$ & $p=0.014$ & $p<0.001$ & $p=0.028$ \\
\hline Steroids & $\begin{array}{l}\text { On steroids } \\
\text { worse }\end{array}$ & NS & - & $\mathrm{p}=0.017$ & NS \\
\hline Antitussives & $\begin{array}{l}\text { On } \\
\text { antitussives } \\
\text { worse }\end{array}$ & $p=0.020$ & NS & NS & - \\
\hline $\begin{array}{l}\text { Baseline } \\
\text { VAS score }\end{array}$ & $\begin{array}{l}\text { Higher } \\
\text { baseline } \\
\text { score } \\
\text { =greater } \\
\text { improvement }\end{array}$ & $p<0.001$ & $p=0.001$ & NS & - \\
\hline Baseline & Higher & NS & - & $p<0.001$ & $p<0.001$ \\
\hline
\end{tabular}


\begin{tabular}{|l|l}
\hline MCLC score & baseline
\end{tabular}

score

=greater

improvement 
Table 5 Clinical factors associated with a change in cough severity. VAS and cough impact MCLCS scores for the "Day 0 - Day 60 interval". NS Non significant; VAS cough severity Visual Analogue Scale; MCLC Manchester Cough in Lung Cancer scale; COPD Chronic Obstructive Pulmonary Disease; PS performance status. */tem 5 of BRI excluded since contained the cough within the question "Are you ever woken up at night by a feeling of heartburn, coughing or choking?"

\begin{tabular}{|c|c|c|c|c|c|}
\hline $\begin{array}{l}\text { Cough } \\
\text { Predictors }\end{array}$ & Description & $\begin{array}{l}\text { Univariate } \\
\text { Analysis } \\
\text { Day 0-60 } \\
\text { Change in } \\
\text { VAS score } \\
n=145\end{array}$ & $\begin{array}{l}\text { Multivariate } \\
\text { Analysis } \\
\text { Day 0-60 } \\
\text { Change in VAS } \\
\text { score } \\
n=145 p<0.001 \\
R^{2} 33 \%\end{array}$ & $\begin{array}{l}\text { Univariate } \\
\text { Analysis } \\
\text { Day 0-60 } \\
\text { Change in } \\
\text { MCLC score } \\
\mathrm{n}=148\end{array}$ & $\begin{array}{l}\text { Multivariate Analysis } \\
\text { Day 0-60 } \\
\text { Change in MCLC score } \\
n=131 \mathrm{p}<0.001 \\
R^{2} 35.7 \%\end{array}$ \\
\hline Age & & NS & - & NS & - \\
\hline Gender & & NS & - & NS & - \\
\hline $\begin{array}{l}\text { Performanc } \\
\text { e Status }\end{array}$ & & NS & - & $p=0.003$ & - \\
\hline Smoking & & NS & - & NS & - \\
\hline Asthma & & NS & - & NS & - \\
\hline COPD & & NS & - & NS & - \\
\hline $\begin{array}{l}\text { Chest } \\
\text { Infection }\end{array}$ & & NS & - & NS & - \\
\hline $\begin{array}{l}\text { Reflux } \\
\text { Disease }\end{array}$ & & $\begin{array}{l}\text { Total score } \\
\text { NS }\end{array}$ & - & \begin{tabular}{ll|} 
Total score \\
NS
\end{tabular} & - \\
\hline Nausea & & & - & NS & - \\
\hline Stage & & NS & - & NS & - \\
\hline Histology & & NS & - & NS & - \\
\hline $\begin{array}{l}\text { Tumour } \\
\text { Location }\end{array}$ & & NS & - & NS & - \\
\hline $\begin{array}{l}\text { Anticancer } \\
\text { Treatment }\end{array}$ & & NS & - & NS & - \\
\hline Opioids & $\begin{array}{l}\text { On opioids at study } \\
\text { entry=greater } \\
\text { improvement }\end{array}$ & $p=0.04$ & NS & $p<0.001$ & $p=0.032$ \\
\hline Steroids & & NS & - & NS & - \\
\hline Antitussive & $\begin{array}{l}\text { On antitussives at } \\
\text { study entry = greater } \\
\text { improvement }\end{array}$ & $p<0.001$ & $p=0.040$ & NS & \\
\hline $\begin{array}{l}\text { Baseline } \\
\text { VAS score }\end{array}$ & $\begin{array}{l}\text { Higher baseline score } \\
\text { =greater } \\
\text { improvement }\end{array}$ & $p=0.018$ & $p<0.001$ & NS & - \\
\hline $\begin{array}{l}\text { Baseline } \\
\text { MCLC } \\
\text { score }\end{array}$ & $\begin{array}{l}\text { Higher baseline score } \\
=\text { greater } \\
\text { improvement }\end{array}$ & NS & - & $p<0.001$ & $p<0.001$ \\
\hline
\end{tabular}




\section{FIGURE LEGENDS}

Figure 1: Recruitment Process. MCLC Manchester Cough in Lung Cancer scale (patient reported); VAS cough severity Visual Analogue Scale (patient reported); CSD Cough Severity Diary (patient reported); BRI Brief Reflux Inventory (patient reported); EORTC QLQ C30+LC13 European Organization for the Research and Treatment of Cancer Quality of Life Core30 questionnaire and Lung Cancer LC13 module (patient reported); CTCAE Common Terminology for Adverse Events cough severity grading scale (patient reported); FU followup; ACM Ambulatory Cough Monitoring

Figure 2: The change in cough scores over time. (a.) Cough frequency was assessed using an objective ambulatory cough monitoring (ACM) at study entry (Day 0) and at Day 60. Data is expressed as number of coughs per hour (c/h) over a 24 hour time period. (b.) Patient responses to Q31 on the EORTC LC 13 which asks patients to rate how much they coughed during the past week. Patient responses were recorded at study entry (Day 0 ) and at Day 60 based on the highlighted categories. Response data is expressed as percentage of overall study population (Day $0, n=173$; Day 60, $n=150$ ). (c.) Cough Severity was assessed using Cough Severity Visual Analogue Scale Scores at study entry (Day 0), Day 30 and Day 60. Data is expressed as millimetre $(\mathrm{mm})$ scores given by patients. Box plots are shown to demonstrate the medians scores given in addition the interquartile and overall range of the data. (d.) Cough grading according to CTCAE grading assessed at study entry (Day 0), Day 30 and Day 60. [Grade 1 defined as Mild symptoms; non-prescription intervention indicated. Grade 2 defined as Moderate symptoms, medical intervention indicated; limiting instrumental Activities of Daily Living (ADL)]. Grade 3 defined as Severe symptoms; limiting self-care ADL. Data is expressed as percentage of overall study population (Day 0, $n=176$; Day 30, $n=133$; Day 60, $n=139$ ). (e.) Cough Severity Diary Scores for patients at study entry (Day 0) and Day 60. Data is expressed as Median score at the time points indicated. (f.) Manchester Cough in Lung cancer Scale Cough Impact Score for patients at study entry (Day 0), Day 30 and Day 60. Data is expressed as median score at the time points indicated. 